\title{
The Talat-Tehlirian Complex: Contentious Narratives of Martyrdom and Revenge in Post-Conflict Societies
}

\author{
ALP YENEN \\ Institute for Area Studies, Leiden University, $N L$
}

\section{INTRODUCTION}

It has been one hundred years since the controversial trial of Soghomon Tehlirian at a district court in Berlin, on 2-3 June 1921. Tehlirian's verdict-not guilty of the murder of Talat Pasha on 15 March 1921-was controversial not only because Tehlirian did not actually deny killing his target, but also because the trial had centered on a politically motivated murder of an internationally wanted war criminal. Born in 1874 to a modest Muslim family in Edirne, Mehmed Talat had risen from employment as a petty post office clerk to become the grand vizier of the Ottoman Empire in its final decade. As one of the revolutionary leaders of the "Young Turk" Committee of Union and Progress (CUP), Talat played a key role in establishing a de facto dictatorship over the empire. Amid the military crisis of the Caucasian front in the First World War, Talat, as the minister of interior, organized the persecutions and deportations of Armenians under the pretext of security measures. In what is known as the Armenian Genocide of 1915, the Armenian population of Anatolia perished as a result of death marches, paramilitary violence, abductions, diseases, and other calamities. ${ }^{1}$ After the

Acknowledgments: An earlier version of this article was presented at the $8^{\text {th }}$ Junior Scholars Convention in Asian Studies, 27-29 April 2016, in Puidoux. I am grateful for the feedback offered by Alexander E. Balistreri, Eldad Ben Aharon, Hüseyin Çiçek, Olmo Gölz, Murat Kaya, Tsolin Nalbantian, Ramazan Hakkı Öztan, Yektan Türkyılmaz, Uğur Ümit Üngör, as well as the anonymous reviewers for $\mathrm{CSSH}$.

${ }^{1}$ For Talat's role in the process, see Taner Akçam, "When Was the Decision to Annihilate the Armenians Taken?" Journal of Genocide Research 21, 4 (2019): 457-80; Hans-Lukas Kieser, Talaat Pasha: Father of Modern Turkey, Architect of Genocide (Princeton: Princeton University Press, 2018), 210-77; Taner Akçam, The Young Turks' Crime against Humanity: The Armenian Genocide and Ethnic Cleansing in the Ottoman Empire (Princeton: Princeton University Press, 2012). 
Ottoman defeat in 1918, Talat and his colleagues fled to Germany in selfimposed exile, escaping the court-martial that sentenced them to death in absentia. Meanwhile, Talat's murderer, Soghomon Tehlirian, a young Armenian, born in 1896 near Erzincan at the Ottoman frontier to the Russian Caucasus, had recently settled as a student in Berlin. What the jury did not know was that Tehlirian was the designated hitman for "Operation Nemesis," a secret assassination campaign of the Armenian Revolutionary Federation (ARF). ${ }^{2}$ Named after the Greek goddess of divine retribution, the leaders of Operation Nemesis coordinated and conducted political assassinations of Turkish perpetrators and Armenian traitors. Talat was at the top of the hitlist.

Talat's assassination and Tehlirian's trial in Berlin in 1921 contributed to the formation of conflicting legacies of the Armenian Genocide and created a significant legal precedent. ${ }^{3}$ Although Raphael Lemkin would coin the legal term "genocide" only in 1944, in 1921 the concept of the murder of a people was not unfamiliar. Talat was considered by the Berlin court in 1921 to be the perpetrator of atrocities against Armenians ("Armeniergräuel") and Tehlirian to be its surviving victim. ${ }^{4}$ Nevertheless, the relationship between Talat and Tehlirian is more complex, not easily reducible to a perpetrator-victim or genocide-homicide dichotomy. The perpetrator of one crime is at the same time the victim of the other crime, committed by the victim of his own deeds. Moreover, both are unequivocally celebrated as heroes by their respective social groups, while their construction as heroes ambiguously draws from the idea that they are being victimized by the respective Other. With their crimes and reputations intertwined, Talat and Tehlirian are coupled in history and memory.

I will call this mutual framework of sensemaking the "Talat-Tehlirian complex." Even though minuscule in terms of its violence and legal ramifications, it constitutes a dominant prism of sensemaking in Turkish-Armenian relations. Talat and Tehlirian are both cast in heroic roles. On one hand, Talat

\footnotetext{
2 A book published in French by Jacques Derogy in 1986 revealed for the broader public that the ARF's clandestine network was behind the revenge killings of the Young Turk leaders. For its English translation, see Jacques Derogy, Resistance and Revenge: The Armenian Assassination of the Turkish Leaders Responsible for the 1915 Massacres and Deportations, A. M. Berrett, ed. and trans. (New Brunswick: Transaction Publishers, 1990).

${ }^{3}$ For its precedence, see Samantha Power, "A Problem from Hell": America and the Age of Genocide (New York: Basic Books, 2002), 1-16; Robert W. D. Kempner, "Vor 60 Jahren vor einem deutschen Schwurgericht: Der Völkermord an den Armeniern," Recht und Politik 3 (1980): 167-69. To be precise, Esad Pasha Toptani's murderer Avni Rustemi had been previously released by a French court, in December 1920, and celebrated as a hero in his homeland. Robert C. Austin, Founding a Balkan State: Albania's Experiment with Democracy, 1920-1925 (Toronto: University of Toronto Press, 2012), 11. See also Isa Blumi, "Divergent Loyalties and Their Memory: How Three Albanians Shaped Their Histories of the Great War," in Olaf Farschid, Manfred Kropp, and Stephan Dähne, eds., The First World War as Remembered in the Countries of the Eastern Mediterranean (Beirut: Ergon Verlag, 2006), 340-42.

4 Stefan Ihrig, Justifying Genocide: Germany and the Armenians from Bismark to Hitler (Cambridge: Harvard University Press, 2016), 271.
} 
Pasha is idealized by many Turks as a hero, the impeccable self-sacrificing defender of the incipient Turkish state and nation against the devious attacks of international terrorists and the intrigues of European great powers. On the other, many Armenians have celebrated Soghomon Tehlirian as a national hero who, as a broken man, overcame his victimhood and punished the monstrous perpetrator of the "Great Crime" (in Armenian: Medz Yeghern) at a moment when the international community had failed to offer a proper prosecution. Talat and Tehlirian are conflicting heroes in contentious narratives of the Armenian Genocide.

There has been no attempt to compare Talat and Tehlirian's mutually exclusive heroizations and cultural legacies. It is indeed a controversial issue. The prevailing hero-villain and perpetrator-victim dichotomies in which they are embedded leave little room for complexity. The disproportionate scale of genocide and homicide makes a normative comparison of perpetration and victimhood truly outrageous. ${ }^{5}$ Furthermore, the direct comparison of Talat and Tehlirian's heroizations is problematic due to asymmetrical relations in power and popularity. Talat's heroization enjoys occasional state sponsorship in Turkey, where the prevailing state nationalism upholds an anti-imperialist and antiminoritarian raison d'état in rejecting genocide claims. The heroization of Tehlirian enjoys more popular support in Armenian remembrance since he embodies not only the traumatic experiences of survival and displacement but also sentiments of retribution and reparation. Although there are institutional efforts in the Republic of Armenia, the heroization of Tehlirian is a mostly decentralized phenomenon across the Armenian diasporas. ${ }^{6}$ Instead of a comparison, therefore, I will offer a connected framework that underlines how Talat's and Tehlirian's respective heroizations are in fact inseparable in their social complexity.

In engaging in such a delicate endeavor, I will combine distinct but related approaches. My understanding of heroes and villains as socially constructed and sustained through constant culture work is informed by a diverse body of scholarship on collective memory. ${ }^{7}$ I take a critical position vis-à-vis the heroic.

\footnotetext{
${ }^{5}$ For an important reminder of certain problems but also prospects of studying mass violence, see Uğur Ümit Üngör, "Studying Mass Violence: Pitfalls, Problems, and Promises," Genocide Studies and Prevention: An International Journal 7, 1 (2012): 68-80. For some of these complexities of mass violence, see also Christian Gerlach, Extremely Violent Societies: Mass Violence in the TwentiethCentury World (Cambridge: Cambridge University Press, 2010). For a critical revision on the neglected agency and violence of genocide victims, see Yektan Türky1lmaz, "Rethinking Genocide: Violence and Victimhood in Eastern Anatolia, 1913-1915" (PhD diss., Duke University, 2011).

${ }^{6}$ It is important to underscore that the Armenian diaspora and the state and society in the Armenian Republic might have very different approaches to key policies with regard to the Armenian Genocide. Khatchik DerGhougassian, "Genocide and Identity (Geo)Politics: Bridging State Reasoning and Diaspora Activism," Genocide Studies International 8, 2 (2014): 193-207.

${ }^{7}$ For a genealogical overview of the field, see Jeffrey K. Olick, Vered Vinitzky-Seroussi, and Daniel Levy, eds., The Collective Memory Reader (Oxford: Oxford University Press, 2011).
} 
This critique is rooted in the sociology of the German Vergangenheitsbewältigung of the Nazi crimes and the Holocaust, which stresses the dangerous consequences of boundary work in the social construction of heroes and villains and therefore calls for a post-heroic reflection on modernity. ${ }^{8}$ Moreover, in explaining how heroic configurations affect later political struggles, I have utilized recent studies on character work in social movement theory, in which historical and political figures are framed as "heroes, villains, victims, and minions" to effect political mobilization. ${ }^{9}$ Based on these approaches, I will address three questions to explain the Talat-Tehlirian complex and its theoretical implications.

First, how do past events continue to shape heroic configurations? History does not simply turn into memory. The narration of events shapes collective memories and new generations create distinct political memories of the past based on their own contingent and partisan positions. ${ }^{10}$ Therefore, historians should critically examine the past independent from the prejudices of social memory. ${ }^{11}$ Groups mobilize political memory, in the form of contentious narratives, not only to compete with one another for recognition but also to make political claims against the interests and reputations of other groups. ${ }^{12}$ By assuming that contentious narratives of the past inform the social construction of heroes and villains, I argue that the ongoing Armenian-Turkish conflict is about not only what happened in Anatolia in 1915, but also what happened in Berlin in 1921.

Second, how are heroization and villainization related? The social construction of villains - commonly in form of a dehumanizing "demonization" shapes political communities and memories as much as heroization does. ${ }^{13}$ The social construction of heroes and villains draws exclusive boundaries of morality

\footnotetext{
8 For recent critical studies of heroism and post-heroism in German social theory, see Johanna Rolshoven, Toni J. Krause, and Justin Winkler, eds., Heroes: Repräsentationen des Heroischen in Geschichte, Literatur und Alltag (Bielefeld: transcript, 2018); Ulrich Bröckling, Postheroische Helden: Ein Zeitbild (Berlin: Suhrkamp, 2020); and Nicole Falkenhayner, Sebastian Meurer, and Tobias Schlechtriemen, eds., "Analyzing Processes of Heroization: Theories, Methods, Histories," helden. heroes. héros., special issue 5 (2019), https://doi.org/10.6094/helden.heroes.heros./2019/ APH. On post-heroic societies, see Herfried Münkler, "Heroische und postheroische Gesellschaften," Merkur: Deutsche Zeitschrift für europäisches Denken 61, 8/9 (2007): 742-52.

9 James M. Jasper, Michael Young, and Elke Zuern, "Character Work in Social Movements," Theory and Society 47, 1 (2018): 113-31, 114. See also James M. Jasper, Michael Young, and Elke Zuern, Public Characters: The Politics of Reputation and Blame (Oxford: Oxford University Press, 2020).

${ }^{10}$ Aleida Assmann, "Transformations between History and Memory," Social Research 75, 1 (2008): 49-72.

11 Paul Connerton, How Societies Remember (Cambridge: Cambridge University Press, 1989), 13-14.

12 For the competition of stories in contentious politics, see Eric Selbin, Revolution, Rebellion, Resistance: The Power of Story (London: Zed Books, 2010), 194.

13 Lori J. Ducharme and Gary A. Fine, "The Construction of Nonpersonhood and Demonization: Commemorating the Traitorous Reputation of Benedict Arnold," Social Forces 73, 4 (1995): 1309-31.
} 
and sacrality. Bernhard Giesen demonstrated how ideal-typical categories of triumphant and tragic heroes, victims, and perpetrators take center stage in the construction of collective identities. ${ }^{14}$ In addition to Giesen's ideal types, Olmo Gölz has offered a "relational framework" that maps out how "positions are constantly renegotiated and rearranged" in what he calls "the imaginary field of the heroic." ${ }^{15}$ Heroization might highlight the simultaneous villainization of another; these heroes and villains stand in relation to other victims and perpetrators. ${ }^{16}$ Given that heroes and villains are social constructions that mutually condition one another, I argue that the heroization of Tehlirian requires the villainization of Talat as much as Talat's heroization requires the villainization of Tehlirian. Although Talat's villainization predates his assassination, Talat and Tehlirian mirror one another in their heroization.

Third, why are certain hero-villain and perpetrator-victim combinations more effective and enduring in political memory than others? Gölz calls for the necessity of overcoming the "either-or" logic of ideal types in favor of more "ambiguous"- but powerful — archetypical heroic configurations that "combine multidimensional discourses in themselves." One such ambiguous figure, Gölz elaborates, is the martyr, who draws social power in collective memory from fulfilling the ideal-typical requirements of hero, victim, and sometimes even perpetrator at the same time. ${ }^{17}$ In the heroic imaginary, whether religious or secular, a martyr offers sovereignty through subversion and salvation through sacrifice. ${ }^{18}$ Another ambiguous and powerful figure that combines multidimensional discourses in a comparable way, I will argue, is the archetype of the avenger. Vengeance is a strong and lasting emotion that transcends the individual and the collective. René Girard pointed out that the "mimetic logic" of vengeance creates a "vicious cycle" that continuously reproduces itself, or, if put into action in form of revenge, even recreates violence. ${ }^{19}$ In explaining how the

14 While offering such ideal types, Bernhard Giesen considers them "liminal figures" who could cross the boundary of the sacred realm; Triumph and Trauma (Boulder: Paradigm Publishers, 2004), $6-7$.

15 Olmo Gölz, "The Imaginary Field of the Heroic: On the Contention between Heroes, Martyrs, Victims and Villains in Collective Memory," helden. heroes. héros., special issue 5 (2019): 27, https://doi.org/10.6094/helden.heroes.heros./2019/APH/04.

16 Ibid., 27.

17 Ibid., 27-32.

18 For martyrdom as sovereignty, see Clayton Fordahl, The Ultimate Sacrifice: Martyrdom, Sovereignty, and Secularization in the West (Abingdon: Routledge, 2020), 19-43; Clayton Fordahl, "Sovereignty and Martyrdom: A Sociological Sketch," Journal of Historical Sociology 31, 3 (2018): 297-313. For martyrdom as subversion, see Olmo Gölz, "Martyrdom and the Struggle for Power: Interdisciplinary Perspectives on Martyrdom in the Modern Middle East," Behemoth-A Journal on Civilisation 12, 1 (2019): 2-13, https://doi.org/10.6094/behemoth.2019.12.1.1013.

19 René Girard, Violence and the Sacred (Baltimore: Johns Hopkins University Press, 1979), 15. See also Patrizia Resta, "The Revenge of Soghomon Tehlirian," Journal on European History of Law 7, 1 (2016): 45-53, 52. 
Talat-Tehlirian complex further complicates Turkish-Armenian relations, I argue that it is their heroic embodiment of martyrdom and revenge that sustains grievances and sacralizes violence across time and space. While Talat embodies the archetype of the martyr and Tehlirian the archetype of the avenger, their mourning communities can search for their own salvation through the imitation of martyrdom or revenge. Beyond a genocide-homicide duality, the Talat-Tehlirian complex is a martyr-avenger complex that shapes and sustains mutual cultures of conflict through the heroic framing of violence, sacrifice, and salvation.

In what follows, I will first offer a critical analysis of the making of contentious narratives during the key historical moments of the Talat-Tehlirian complex in Berlin 1921, in three acts: the assassination, the funeral, and the trial. After that, I will illustrate contentious narratives of Talat and Tehlirian across different generations. In the conclusion, I will discuss the theoretical implications of the martyr-avenger complex in post-conflict societies in the hope that it will contribute to a transition to a post-heroic age in Turkish-Armenian relations.

\section{THE ASSASSINATION: A DISPUTED DRAMATURGY OF REVENGE}

In 1921, Talat was already a villain in the eyes of the international public. The revelation of the deportations and massacres of the Armenians after 1915 made Talat into an international villain and the embodiment of an Oriental despot within the prevailing civilizational discourse of war propaganda. ${ }^{20}$ After disappearing from the capital, Talat and his colleagues were sentenced to death by a court-martial of the postwar government in Allied-occupied İstanbul for their "crimes against humanity." ${ }^{21}$ When he crossed paths with his assassin, Talat was hiding in plain sight in Berlin, preparing for his return to politics in Turkey. ${ }^{22}$ Soghomon Tehlirian was recruited as a young, desperate man by the ARF in postwar İstanbul to kill an Armenian collaborator, Harutiun Megerdichian. ${ }^{23}$ After killing Megerdichian, Tehlirian was promoted to the secretive assassination team organized under Operation Nemesis. Tehlirian traveled to Boston to

\footnotetext{
20 Most notably after Henry Morgenthau, Ambassador Morgenthau's Story (New York: Doubleday, Page \& Co., 1918). For issues of Orientalism in the contemporary representations of the Armenian Question, see Jo Laycock, Imagining Armenia: Orientalism, Ambiguity and Intervention (Manchester: Manchester University Press, 2009).

${ }_{21}$ Vahakn N. Dadrian and Taner Akçam, Judgment at Istanbul: The Armenian Genocide Trials (New York: Berghahn Books, 2011), 16.

22 For more context, see Alp Yenen, "The Young Turk Aftermath: Making Sense of Transnational Contentious Politics at the End of the Ottoman Empire, 1918-1922" (PhD thesis, University of Basel, 2016); published online in 2019: https://doi.org/10.5451/unibas-007110817.

${ }^{23}$ Lindy V. Avakian, The Cross and the Crescent (Phoenix: UCS Press, 1989), 47-53. For collective feelings of revenge among the Armenian community in İstanbul, see Lerna Ekmekçioğlu, Recovering Armenia: The Limits of Belonging in Post-Genocide Turkey (Stanford: Stanford University Press, 2016), 45-50.
} 
receive instructions from Armen Garo (Karekin Pastermadjian). ${ }^{24}$ The field operator of the operation in Europe, Shahan Natalie (Hagop Ter Hagopian) and his team had already found Talat living in Berlin at Hardenbergstraße 4 under a pseudonym. ${ }^{25}$ Tehlirian returned to Europe and settled in Berlin as a mechanical engineering student, renting a room across the street from Talat's flat.

On the morning of Tuesday, 15 March 1921, Soghomon Tehlirian was secretly observing Talat's flat from his window. After Talat left the house around 11 o'clock, Tehlirian grabbed his gun and went after him. Only a few days prior, he had received the ARF's order: "The time has come to go into action. We order you to kill Talaat without delay and to leave the other criminals be, even if it means they escape." 26 Tehlirian did not hesitate. He followed Talat on the street and killed him with a single shot to the head. "The monster fell on the ground," wrote Tehlirian in his memoir. ${ }^{27}$

The ancient law "an eye for an eye," suggests not only a proportionality of the retaliation - a problematic proposition in cases of mass violence-but also the intimacy of the punishment. An important feature of Tehlirian's heroization is, therefore, how Tehlirian narrated his act of killing in an attempt to position himself in the social imagination of others. Tehlirian claimed in his court testimony to have passed by Talat while looking him in the eye just before turning around and shooting him in the back of the head. ${ }^{28}$ This brief moment of looking in the eyes is important in Tehlirian's narratives to humanize the act of killing. ${ }^{29}$ However, eyewitnesses testified that Tehlirian actually approached Talat at a great pace from behind and shot him directly in the back of the head. ${ }^{30}$ Narratives that take Talat's side describe the act of killing from behind as "cowardly." 31 The image of Talat being killed from the back by an Armenian is commonly embedded in the stab-in-the-back legends so prominent in narratives of Ottoman

24 Eric Bogosian, Operation Nemesis: The Assassination Plot that Avenged the Armenian Genocide (New York: Little, Brown and Co., 2015), 141-42.

25 Marian Mesrobian MacCurdy, Sacred Justice: The Voices and Legacy of the Armenian Operation Nemesis (New Brunswick: Transaction Publishers, 2015), 182; Bogosian, Operation Nemesis, 184. See also Derogy, Resistance and Revenge, 83.

${ }^{26}$ Quoted in Derogy, Resistance and Revenge, 84.

27 Soghomon Tehlirian, Verhishumner: (T'aleat'i Ahabekume), Vahan Minakhorian, ed. (Cairo: Housaper, 1956), 195, quoted in MacCurdy, Sacred Justice, 139.

28 Armin T. Wegner, ed., Der Prozeß Talaat Pascha: Stenographischer Bericht über die Verhandlung gegen den des Mordes an Talaat Pascha angeklagten armenischen Studenten Salomon Teilirian vor dem Schwurgericht des Landgerichts III zu Berlin Aktenzeichen: C. J. $2221 \mathrm{am}$ 2. und 3. Juni 1921 (Berlin: Deutsche Verlagsgesellschaft für Politik und Geschichte, 1921), 21-22.

${ }_{29}$ Michael Bobelian, Children of Armenia: A Forgotten Genocide and the Century-Long Struggle for Justice (New York: Simon \& Schuster, 2009), 61. The Armenian Genocide Museum in Yerevan also prefers this version. See: http:/www.genocide-museum.am/eng/soghomon-tehlirian-eng.php (last accessed 12 May 2021).

30 Wegner, Der Proze $\beta$ Talaat Pascha, 25-29.

31 M. Mansur Rifat, Talaat Paschas Prozeß, sein Verlauf und sein Ende: Ein letztes Wort zur armenischen Frage; Nachtrag zu "Das Geheimnis der Ermordung Talaat Paschas" (Berlin: Morgen- und Abendland-Verlag, 1921), 23. 
collapse. As such, Tehlirian's singular violence is recast as the collective treachery of Armenians. This creates a toxic dialectic. For example, Aram Andonian, an Armenian intellectual and survivor of the initial arrests of 24 April 1915, rejected Turkish claims that Tehlirian was a "coward" for shooting Talat from behind and argued that "Tehlirian, who followed Talaat on Hardenberg Strasse in Charlottenburg, could have shot Talaat in the back, but he chose to pull the trigger while facing him, after he had called out his name." 32 This version where Tehlirian "shot him in the forehead and knocked him down" is even popularized in an Armenian folk song. ${ }^{33}$ In Avakian's edition of Tehlirian's memoir, meanwhile, Tehlirian pulls out the gun and directs it at Talat's face, but Talat turns around in fear and gets shot in the back of the head. ${ }^{34}$ Other versions depict Tehlirian as impersonating a Turk before killing Talat at point blank. When featured in Turkish narratives, this version feeds into the tropes of Armenian deception. ${ }^{35}$ In all cases, how the act of killing is narrated is crucial for the subjective positioning of the narrator.

The avenger can only become a hero if the revenge is made public because a revenge killing kept secret is difficult to distinguish from murder. Tehlirian was clearly instructed by Shahan Natalie to "stay at your place with your foot on the head of the dead body and you will surrender to the policemen who come, who arrest you." 36 As a new type of assassin, as Hannah Arendt noted, Tehlirian voluntarily "insisted on being tried" in order to "show the world through court procedure what crimes against his people had been committed and gone unpunished." ${ }^{37}$ Before Tehlirian could take a triumphant posture, however, he was jumped by an enraged mob of pedestrians and saved by the police who arrested him. ${ }^{38}$ "Me Armenian, he Turkish. No harm for Germany," Tehlirian uttered in broken German, again and again, first to the mob that was beating him and later to the police questioning him. ${ }^{39}$ He learned this line in order to frame the revenge killing as a blood feud between two parties.

32 Aram Andonian, Exile, Trauma, and Death: On the Road to Chankiri with Komitas Vartabed, Rita S. Kuyumjian, ed. (London: Gomidas Institute, 2010), 2; reacting against Hüseyin Cahit Yalçın, Talat Paşa (İstanbul: Yedigün Neșriyatı, 1943), 63.

33 Quoted in Verjiné Svazlian, The Armenian Genocide and the People's Historical Memory (Yerevan: Gitutiun Publishing House of the NAS RA, 2005), 88.

34 Avakian, Cross and the Crescent, 14-41.

35 This version originates partly from the news coverage. See, for example, "How Talaat Pasha Was Shot: Armenian's Story of Vengeance," Times (London), 17 Mar. 1921. For the adoption of this version in Turkish historiography, see Hasan Babacan, Mehmed Talat Paşa: 1874-1921 (Siyasi Hayatı ve Ícraatı) (Ankara: Türk Tarih Kurumu Yayınları, 2005), 229.

36 Quoted in Bogosian, Operation Nemesis, 140.

37 Hannah Arendt, Eichmann in Jerusalem: A Report on the Banality of Evil, revised and enlarged ed. (New York: Viking Press, 1964), 265-66.

38 Wegner, Der Prozeß Talaat Pascha, 24-25. See also Rolf Hosfeld, Operation Nemesis: Die Türkei, Deutschland und der Völkermord an den Armeniern (Köln: Kiepenheuer \& Witsch, 2005), 9.

39 Wegner, Der Prozeß Talaat Pascha, 21, 28. See also: Hosfeld, Operation Nemesis, 9; Bogosian, Operation Nemesis, 11. 
The heroization of an avenger starts once the act of revenge is approved by a wider community as retributive justice. Although most conservative newspapers in Germany remained loyal to the Turkish cause, international and leftist newspapers were quick to frame the killing in terms of righteous revenge or tyrannicide, even depicting Tehlirian as the William Tell of Armenia. ${ }^{40}$ When the prosecutor's Armenian interpreter George Kalusdian brought sweets and chocolate to Tehlirian at the police headquarters, the prosecutor asked why he was bringing treats to a murderer. Kalusdian protested: "What, a murderer? This is a great man, whom we all adore!" 41 In fact, the chief public prosecutor was concerned that "the defense counsel will argue on behalf of the accused that his was an act of heroism freeing Christian Armenians suffering under the Turkish yoke." 42 "Son, you are not only a hero to the Armenians but to the Greek people as well," congratulated a Greek priest in a letter to Tehlirian as he awaited trial. The act was embedded in the prevailing Orientalism that depicted the Armenian massacres as archaic barbarism. "Every Christian and civilized nation in the world will soon know you as their international hero." 43 The heroization of Tehlirian as an avenger was already confirmed at this early stage by his own community and beyond.

\section{THE FUNERAL: A PARADE OF IMMORTALIZING A "STATESMAN"}

When Talat's friends rushed to the crime scene, they asked to have the body lying on the street transported to the morgue immediately, but the police officer insisted on waiting for the homicide squad to arrive. Talat's friends considered it a disgrace to the deceased, in their eyes a martyr, that his body was left disrespected and unprotected on the ground. Talat's political advisor and friend Dr. Ernst Jäckh had to call the police chief from a nearby telephone and convince him that 'the man lying in the street was, in a way, the 'Turkish Bismarck' and our loyal ally in the war." ${ }^{44}$ Talat's reputation as a martyred statesman, however, was contested in the public. Talat was depicted by the international media as a

40 “Talaat Pasha Murdered: Armenian's Vengeance," Times (London), 16 Mar. 1921. For the comparisons with Tell, see Vorwärts, "Der GroBkriegsverbrecher," 4 June 1921, quoted in Stefan Ihrig, "Genocide Denied, Accepted, and Justified: The Assassination of Talât Pasha and the Trial of His Assassin (1921) as a Media Event in the Early Weimar Republic," Journal of the Society for Armenian Studies 22 (2013): 153-77, 167. See also Heinrich Vierbücher, Armenien 1915: Was die kaiserliche Regierung den deutschen Untertanen verschwiegen hat: Die Abschlachtung eines Kulturvolkes durch die Türken (Hamburg: Fackelreiter, 1930), 6-8.

41 Wegner, Der Proze $\beta$ Talaat Pascha, 46.

42 Quoted in Tessa Hofmann, "New Aspects of the Talat Pasha Court Case: Unknown Archival Documents on the Background and Procedure of an Unintended Political Trial," Armenian Review 42, 4/168 (1989): 41-53, 44.

${ }_{43}$ Avakian, Cross and the Crescent, 189.

44 Jäckh to Zeki Pasha, 17 Mar. 1921, in Ernst Jäckh, The Rising Crescent: Turkey Yesterday, Today, and Tomorrow (New York: Farrar \& Rinehart, 1944), 269. For a similar comparison by Alfred Nossig in 1916, see Dominik J. Schaller, "Die Rezeption des Volkermordes an den Armeniern in 
cunning criminal and an Oriental despot, "who with more education and in better surroundings might have become a statesman." ${ }^{45}$ In response, Talat's mourning community devoted their efforts to immortalize their martyr as a great statesman.

The preservation of the body enables the continuation and repetition of the cult of martyrdom. ${ }^{46}$ A martyr's body possesses a symbolic power in the imaginary field of the heroic, enabling his surviving followers to capitalize on it for their own causes. Instead of a regular burial within a few days that accorded with Muslim customs, Talat's body was embalmed "for a hundred years," as his wife proudly noted. ${ }^{47}$ His embalmed body was placed in a zinc coffin covered in a red flag with a white crescent and with a fez at its head, signifying him as a Muslim statesman. ${ }^{48}$ The immortalization of Talat's body was so important for the Young Turk community in Berlin that they employed a German sculptor, Georg Kolbe, to build a bust of Talat based on a clay impression of his damaged head. ${ }^{49}$ One of Talat's accomplices, Dr. Nazım, was very conscious that they were creating what one might consider a Durkheimian civic religion out of Talat's commemoration. "There is no doubt that for those who appreciate Talat's greatness," he wrote a colleague, Talat's bust "will have the same effect that Jesus has on a devout Christian." 51

The willingness for self-sacrifice is a heroic gesture and a fundamental condition of martyrdom. ${ }^{52} \mathrm{~A}$ mythological feature of the Turkish narratives depicts Talat as prophesying his own assassination and accepting it as his destiny. Once warned about Armenian assassins, as popular historian Cemal Kutay tells it, Talat had allegedly responded: "What can any of us do, when death comes

Deutschland," in Hans-Lukas Kieser and Dominik J. Schaller, eds., Der Völkermord an den Armeniern und die Shoah (Zürich: Chronos Verlag, 2002), 529.

45 “Talaat's Career: Exterminator of Armenians," Times (London), 16 Mar. 1921.

46 Michaela DeSoucey et al., "Memory and Sacrifice: An Embodied Theory of Martyrdom," Cultural Sociology 2, 1 (2008): 99-121.

47 Murat Bardakçı, "Interview with Hayriye Talat Bafralı, October 1982," in Murat Bardakçı, ed., Talat Paşa 'nın Evrak-ı Metrukesi: Sadrazam Talat Paşa'nın Özel Arşivinde Bulunan Ermeni Tehciri Konusundaki Belgeler ve Hususi Yazışmalar (İstanbul: Everest, 2009), 222.

48 Deutsche Allgemeine Zeitung, 19 Mar. 1921, evening ed., quoted in Gerhard Höpp, "Tod und Geschichte oder Wie in Berlin prominente Muslime bestattet wurden," in Gerhard Höpp and Gerdien Jonker, eds., In fremder Erde: Zur Geschichte und Gegenwart der islamischen Bestattung in Deutschland (Berlin: Verlag Das Arabische Buch, 1996), 23.

49 Nazım (Berlin) to Cavid (Switzerland), [21 Mar. 1921], in Hüseyin Cahit Yalçın, Itttihatçı Liderlerin Gizli Mektuplarl: Bir Devri Aydınlatan Tarihi Mektuplar, Osman Selim Kocahanoğlu, ed. (İstanbul: Temel Yayınları, 2002), 106. A photograph of the bust is printed in Kieser, Talaat Pasha, 287.

50 For similar dynamics, see Peter Wien, "The Long and Intricate Funeral of Yasin Al-Hashimi: Pan-Arabism, Civil Religion, and Popular Nationalism in Damascus, 1937," International Journal of Middle East Studies 43, 2 (2011): 271-92.

51 Nazım (Berlin) to Cavid (Switzerland), 2 Apr. 1921, in Yalçın, Ittihatçı Liderlerin Gizli Mektuplarl, 111-13.

52 Gölz, "Martyrdom and the Struggle for Power," 6. 
around?"53 On another occasion when a concerned friend asked Talat what he would do against Armenian assassins, Talat had supposedly joked: "Maybe I want to die by an Armenian bullet." 54 The narrative has it that Talat would say to his wife, "One day they will kill me walking in the street. I will not be granted a death in my comfortable bed.... Prepare yourself for this!" 55 When his friends warned him about going out on the street on his own in Berlin, he replied, "If someone decides to shoot a man, he comes around and shoots him; it is not possible to prevent this." 56 Before leaving home for the last time, Talat is said to have told his wife while standing at the door: "I don't know. I have a funny feeling." 57 "True martyrs know what they are doing," cultural sociologists remind us. ${ }^{58}$ The lack of prophesy would deny the deceased the core tenet of martyrdom, the willingness for self-sacrifice.

There is a retrospective fatalism in the cult of martyrdom that decodes unjust mortal victimization as the heroic price of a sacred struggle. Talat's friends depicted his martyrdom as the honorable duty of a soldier. Speaking of Talat's death, one of his colleagues said to another: "It is a blessing that late Talat's life has been crowned with martyrdom. As long as death is the end, it is best to die like this."59 "His time had come!" was the reaction of Talat's Young Turk colleague and the former minister of war Enver Pasha. ${ }^{60}$ "Poor Talat Pasha's murder really shocked us," wrote another. "But what can we do, the pitcher goes so often to the well, that it is broken in the end." 61 By depicting the martyrdom as a self-chosen soldierly destiny, however, his mourning community implicitly conceded that Talat deserved the animosity of Armenians.

Commemorations of martyrs are always contentious performances, in which the mourning community honors the martyrs and condemns the

53 Quoted in Cemal Kutay, “Talat Pașanın Berlindeki Son Günleri,” Tarih Konuşuyor 1, 2 (1964): $133-36,133$.

54 Kutay, "Talat Pașanın Berlindeki Son Günleri,” 134.

55 Salahhadin Öngör, "Talat Paşa’ya Dair Hatıralar," Cumhuriyet, 27 Feb. 1943, 2, quoted in Hikmet Özdemir, Üç Jöntürk'ün Ölümü: Talat, Cemal, Enver (İstanbul: Remzi Kitabevi, 2007), 35-36.

56 Arif Cemil Denker, Ittihatçı Şeflerin Gurbet Maceraları, Yücel Demirel, ed. (İstanbul: Arma Yayınlar1, 1992), 31, originally published as a series in Tevhid-i Efkar from 14 May to 13 July 1922. A similar but different version is also quoted in Arif Cemil Denker, Talat Paşa'nın Son Günleri: Bir Türk Vurulmuş Diyorlar (İstanbul: Kronik Yayınları, 2020), 70, originally published as a series in Son Posta from 21 Aug. to 21 Oct. 1937.

57 Kutay, "Talat Paşanın Berlindeki Son Günleri," 135.

58 Jasper, Young, and Zuern, Public Characters, 216.

59 Shakib Arslan (Berlin) to Enver (Moscow), 21 Mar. 1921, Archive of the Turkish Historical Society, Ankara (Türk Tarih Kurumu, hereafter TTK), Enver Pasha Papers 02-20.

${ }^{60}$ Louise Bryant, Mirrors of Moscow, repr. (Westport: Hyperion Press, 1973), 159. See also Enver (Moscow) to Naciye (Berlin), 17 Mar. 1921, in Murat Bardakçı, ed., Naciyem, Ruhum, Efendim: Enver Paşa 'nın, Eşi Naciye Sultan'a Rusya ve Orta Asya'dan Yazdığı Sürgün Mektupları (İstanbul: Türkiye İş Bankası Kültür Yayınları, 2016), 91.

61 Küçük Talat [Mușkara] (Trabzon) to Enver(Moscow), 28 Apr. 1921, TTK, Enver Pasha Papers 01-06. 
murderers. In calling for the solidarity of the German public, the Young Turk community's German supporters in Berlin idealized Talat as a great statesman loyal to Germany. For instance, while openly condemning his "sin" in the Armenian deportations, a German diplomat in his memoir commemorated Talat as follows: "With complete integrity, he was a man of rare gifts, which enabled him to traverse the steep climb from simple telegraph clerk to senior statesman, that is, a statesman in the true sense of the word." 62 Conservative German newspapers conveniently ignored Talat's "revolutionary" background, because Talat was a "statesman" above all else. ${ }^{63}$ Tehlirian and Talat were contrasted with each other. Accounts sympathetic to Talat infantilized Tehlirian as a "murder boy" ("Mordbube"), while Talat was depicted as an "elder" statesman-though he was only forty-seven. ${ }^{64}$ The funeral wreath placed near the coffin echoed the official German motto: "A great statesman and a loyal friend." 65 The prestigious funeral was organized from the start as a semi-official state ritual. Eulogies and obituaries repeated that Talat was an honest and respected statesman with great achievements. In the words of Dr. Jäckh's obituary: "With Talat, a statesman is eliminated, a born 'statesman,' one of the few real statesmen of historic proportions and stature in this present time that is short of leader personalities."

Since martyrdom is a contested death, its causes must be explained by the mourning community as worthy of the ultimate sacrifice. The fact that Tehlirian was part of an ARF assassination team long remained a secret. ${ }^{67}$ The Young Turk community in Berlin, however, rightly assumed that he was part of a larger ARF assassination plot. ${ }^{68}$ Nevertheless, the common explanation was that the ARF was not acting on its own either but following the orders of the great powers. The simple formula was: "England's felonious hand everywhere." ${ }^{69}$ His followers

62 Johann Heinrich von Bernstorff, Erinnerungen und Briefe (Zürich: Polygraphischer Verlag, 1936), 126.

${ }^{63}$ Ihrig, "Genocide Denied," 164.

${ }^{64}$ Quoted from Deutsche Allgemeine Zeitung, in Hosfeld, Operation Nemesis, 13.

65 Hosfeld, Operation Nemesis, 12.

${ }^{66}$ Ernst Jäckh, "Talaat," Deutsche Politik 6, 14 (1921): 315-22, 315.

67 The ARF's involvement was already revealed in Oliver Baldwin, The Questing Beast: An Autobiography (London: Grayson \& Grayson, 1932), 201-4, but it was mostly ignored. Former Nemesis operatives, including Tehlirian, wrote their memoirs in Armenian during the 1950s and 1960s.

${ }^{68}$ Cemal Hayri (Berlin) to Enver (Moscow), 28 Mar. 1921, TTK, Enver Pasha Papers 07-27; Nazım (Berlin) to Enver (Moscow), 27 Mar. 1921, in Masayuki Yamauchi, ed., The Green Crescent under the Red Star: Enver Pasha in Soviet Russia, 1919-1922 (Tokyo: Institute for the Study of Languages and Cultures of Asia and Africa, 1991), 185-87. Tehlirian's case files indicate that the Young Turk community suspected the complicity of the Armenian Embassy. Osik Moses, "Assassination of Talaat Pasha in 1921 in Berlin: A Case Study of Judicial Practices in the Weimar Republic" (MA thesis, California State University, 2012), 45.

69 M. Mansur Rifat, Das Geheimnis der Ermordung Talaat Paschas: Ein Schlüssel für das englische Propagandasystem (Berlin: Morgen- und Abendland-Verlag, 1921), 25. 
claimed that Talat was martyred because he was struggling for the defense of the Muslim world against Western colonialism and imperialism. It was public knowledge that Talat has been supporting the Turkish War of Independence under the leadership of Mustafa Kemal (Atatürk) and was connected to anticolonial Muslim activist networks. ${ }^{70}$ Again in Jäckh's dramatic words, "Constantinople and Angora roar with anger and clench their fists - and, along with the Turkish people, an Islamic world of Arabs and Tatars, Persians, Indians, and Afghans, all have sworn allegiance to Talat's corpse at the Berlin cemetery, as he was the intrepid, tireless champion of the oppressed peoples against English and French imperialism."71 All of the Eastern orators at Talat's funeral framed the assassination "not as the consequence of a private or national vengeance, but rather as the result of an imperialist policy executed against the Muslim peoples." 72 Jäckh, too, claimed in his obituary that the reason behind the assassination was the Entente's fear of Talat's impending return to Turkey: "London and Paris breathe a sigh of relief and gratefully acknowledge the Armenian assassin." 73 Still today in Turkish narratives of the assassination Britain's alleged role is an important explanatory factor. ${ }^{74}$

The greater cause for the sacrifice of the martyr can even downplay the significance of the perpetrator. One indirect consequence of seeing the British as pulling the strings behind the assassination is the implication that the Armenians were rendered incapable of acting on their own - they are framed as the lesser evil in a greater struggle. In an obituary Enver Pasha published anonymously, he claimed, "It is by no means possible for Armenians to undertake this plot because of the Armenian deportations." According to Enver, behind this Armenian student stood Armenia's "big brother," England. ${ }^{75}$ Turkish narratives, then and now, thereby deny Armenians even the status of actual villain. Armenians are reduced to the character-work category of minions "who are malevolent but too weak to be much of a threat until they hook up with a villain." "76 While Tehlirian and Armenians were disregarded as the minions of great powers, Talat's martyrdom was represented as the culmination of the collective suffering of Turks and Muslims at the end of the Ottoman Empire. It resonated with existing tropes in Turkish nationalist propaganda that regarded the Turkish

\footnotetext{
70 Alp Yenen, "Elusive Forces in Illusive Eyes: British Officialdom's Perception of the Anatolian Resistance Movement," Middle Eastern Studies 54, 5 (2018): 788-810.

71 Jäckh, "Talaat," 315.

72 Nazım (Berlin) to Cavid (Switzerland), [21 Mar. 1921], in Yalçın, Ittihatçı Liderlerin Gizli Mektupları, 107. See also Denker, Talat Paşa'nın Son Günleri, 145-46.

73 Jäckh, "Talaat," 315.

74 Babacan, Mehmed Talat Paşa, 212-13. It is not far-fetched to speculate about British interests behind the assassination, and a few Armenian authors considered it too (for example Bogosian, Operation Nemesis, 176), but it remains unproven.

75 [Enver], “Talat Pașa ve Katili," Liwa-el-Islam 1, 7 (15 June 1921): 75.

76 Jasper, Young, and Zuern, Public Characters, 4.
} 
people as being collectively "assassinated" and "martyred" at the hands of the international community. ${ }^{77}$

\section{THE TRIAL: AN AMBIGUOUS ACQUITTAL OF AN AVENGER}

Beyond assuring the commitment of their own sympathetic communities and framing their cause for a broader public to find more followers, contentious narratives of martyrdom and revenge ideally seek the certification of a third party that should judge and honor the human sacrifice. ${ }^{78}$ The public legitimacy of Talat's martyrdom and Tehlirian's revenge depended on the outcome of the trial. While generally underestimated as unworthy villains, the only agency attributed to Armenians by their Turkish counterparts was their ability to propagandize their cause out of proportion. "The Armenians here are working to mitigate the murderer's punishment," wrote Dr. Nazim with great concern. ${ }^{79}$ Indeed, the ARF and other Armenian organizations were involved in public propaganda. Shahan Natalie noted that the event had become not only "a sacred work of justice but also an occasion to propagandize the Armenian case...." ${ }^{80}$ In Turkish narratives, however, Armenian propaganda during Tehlirian's trial is seen as manipulating public opinion in Germany against the Turks. ${ }^{81}$ His trial along with its media coverage featured the first fully fledged versions of contentious narratives of the Armenian Genocide, which endure today. ${ }^{82}$

Unlike a vigilante, the avenger needs a personal background story of victimization to justify a violent retaliation. Tehlirian's defense council effectively shifted the focus from the murder to what happened in Anatolia in 1915. In support, Aram Andonian arrived in Berlin and presented to Tehlirian's defense council a collection of telegrams (the so-called Talat Pasha telegrams) proving

77 Galib Kemali [Söylemezoğlu], Le martyre d'un peuple: les Turcs demandent une paix juste, prompte et durable (Rome: Imprimérie Riccardo Garroni, 1919); Galib Kemali [Söylemezoğlu], Assassinat d'un peuple: suite au "Martyre d'un peuple” (Rome: Imprimérie Riccardo Garroni, 1921).

78 Girard, Violence and the Sacred, 52-53.

79 Nazım (Berlin) to Cavid (Switzerland), 2 Apr. 1921, in Yalçın, Ittihatçı Liderlerin Gizli Mektuplarl, 111-13.

80 Shahan Natalie (Amsterdam) to the ARF Central Committee of America (Boston), 19 Mar. 1921, in MacCurdy, Sacred Justice, 203.

81 See, for example: Mustafa Çolak, “'Tehcir Olayı'nın Propaganda Sürecindeki Doruk Noktası: ‘Talat Paşa Davası,'” Atatürk Araştırma Merkezi Dergisi 10, 58 (2004): 1-46; Ramazan Çalık, "Talat Pașa'yı Vuran Teröristin Affının Alman Basınındaki Yankısı,” in Kemal Çiçek, ed., Pax Ottomana: Studies in Memoriam Prof. Dr. Nejat Göyünç (Haarlem, Netherlands, Ankara: SOTA; Yeni Türkiye, 2001), 465-504. Regardless of "Armenian propaganda," the German public was well aware of the culpability of the Young Turk government. Margaret L. Anderson, "Who Still Talked about the Extermination of the Armeniens? German Talk and German Silences," in Ronald G. Suny, Fatma Müge Göçek, and Norman M. Naimark, eds., A Question of Genocide: Armenians and Turks at the End of the Ottoman Empire (Oxford: Oxford University Press, 2011), 207.

82 Ihrig, Justifying Genocide, 193-297. 
that Talat gave secret orders to exterminate the Armenian population. ${ }^{83}$ The Young Turk community in Berlin quickly rejected these as forgeries, as have Turkish and many international historians until recently, ${ }^{84}$ and the Berlin court, too, refused to accept them as evidence. ${ }^{85}$ Instead, experts and witnesses gave testimony to establish the story of what happened in Anatolia in 1915.

In a world of injustice, the avenger possesses a personal story of suffering that also represents a generally recognizable collective victimization. Tehlirian's court testimony was carefully prepared to conceal critical details from his past. When the war started in 1914, Tehlirian had not been in Anatolia, but in Serbia studying mechanical engineering. He immediately traveled to Tiflis and enlisted in the Armenian Volunteer Units of the Russian army that fought against the Ottoman army. This fact not only did not fit into his traumatized survivor persona but would have surely upset the German jury's sympathies as well. In March 1916, as Tehlirian entered his destroyed hometown together with Russian forces, he found out that his whole family had perished. ${ }^{86}$ Concealing these facts and adapting his biography to the general narrative of what happened in 1915, Tehlirian told in court that he had witnessed the brutal massacres of his family in Erzincan, including the abduction of sisters he never had, and that he had barely survived the onslaught. Motivated by the haunting hallucinations of his dead mother, he said that he planned the murder on his own. Tehlirian's testimony helped to frame him as a "hero of endurance," admired "for their ability to survive rather than to dominate others." They "can remain faceless and collective." ${ }^{97}$ Combined with other testimonies, Tehlirian's story was touching and certainly affected the course of the trial, helping to recast him as the "righteous avenger." 88

83 Aram Andonian, The Memoirs of Naim Bey: Turkish Official Documents Relating to the Deportation and the Massacres of Armenians (London: Hodder and Stoughton, 1920).

${ }^{84}$ See M. Masur Rifat's afterword in Shakib Arslan, Das armenische Lügengewebe: Frivole Haltung der Gönner Armeniens (Berlin-Charlottenburg: Morgen- und Abendland-Verlag, 1921), 26. See also Denker, Talat Paşa'nın Son Günleri, 182-83. First published in Turkish in 1983, Turkish historians demonstrated that there were major inconsistencies in the names, dates, signs, signatures, and language of the telegrams. Şinasi Orel and Süreyya Yuca, The Talat Pasha "Telegrams": Historical Fact or Armenian Fiction? (Nicosia: Rustem, 1986). While the telegrams remained long distrusted by historians, a new study reclaims their authenticity. Taner Akçam, Killing Orders: Talat Pasha's Telegrams and the Armenian Genocide (Basingstoke: Palgrave Macmillan, 2018).

${ }^{85}$ The telegrams were published in George R. Mongomery, "Why Talaat's Assassin Was Acquitted," Current History 14, 4 (July 1921): 271-74; in the appendix of Wegner, Der Prozeß Talaat Pascha, 133-36; and in Johannes Lepsius, "Der Prozess Teilirian-Talaat," Der Orient 3, 6 (1921): 65-80, 88-95, 69.

86 Avakian, Cross and the Crescent, 33-46.

87 Jasper, Young, and Zuern, Public Characters, 214. Genocide survivors are commonly depicted as "heroes of endurance." Elke Zuern and James M. Jasper, "Heroes and Victims in Divided Nationalism: The Case of Namibia," Journal of Nationalism, Memory \& Language Politics 14, 1 (2020): 1-27, 18.

88 Carolyn J. Dean, The Moral Witness: Trials and Testimony after Genocide (Ithaca: Cornell University Press, 2019), 33, 59. 
The more authentic the avenger's individual story of suffering is, the more the revenge killing is framed as an individual crime of passion. "Apply every means there to prove that that was an individual act," was one of the ARF orders to Tehlirian's team in Berlin. ${ }^{89}$ Hence, the involvement of the ARF and Tehlirian's previous murder of Megerdichian, or the fact that he served in the war as a volunteer soldier, were concealed. That Tehlirian altered and concealed his real life story feeds into the martyrology of Talat, who is imagined as having fallen victim to a fraudulent conspiracy. Contrary to Turkish nationalist narratives' insistence, however, Tehlirian's testimony did not fabricate but rather imagined what happened in Anatolia in 1915. ${ }^{90}$ That is, Tehlirian may not have witnessed the persecution of his family in person, as he told the jury, but he did see the devastating landscape of extermination in its aftermath. Genocide is an indiscriminate form of violence that makes people like Tehlirian, too, a victim and survivor. In Holocaust studies, however, the inauthenticity of survivor memoirs is a more contentious matter. ${ }^{91}$ As for Armenian nationalist narratives, Tehlirian's conflicting narratives are not a cause for concern, because Tehlirian's heroization as an avenger assumes a dual quality in which he is at once a traumatized survivor and a committed volunteer fighter (fedayi). Nevertheless, that some genocide scholars simply prefer to retell Tehlirian's dramatic court testimony instead of his actual biography is indicative of the prevailing moralism of the victim-perpetrator binary. ${ }^{92}$

An avenger must always display vulnerability and trauma because, in need of formal certification, the avenger cannot come across as a cold-blooded murderer. Besides concealing his past as an Armenian soldier and assassin, Tehlirian's mental problems helped to frame him as a desperate man. He was attested to

${ }^{89}$ Armen Garo (Paris) to ARF Central Committee of America, 17 Mar. 1921, in MacCurdy, Sacred Justice, 200.

90 Tehlirian's imagined testimony is a major part of Turkish nationalist narratives that depict Armenians as liars and deceivers. For instance, one of the oldest internet sites dedicated to the denial of the Armenian Genocide, named Tall Armenian Tale, refers to Tehlirian as a "total liar" in a long page about his trial in Berlin, http://www.tallarmeniantale.com/trial.htm (last accessed 12 May 2021). For the general pattern, see Gwynne Dyer, “Turkish 'Falsifiers' and Armenian 'Deceivers': Historiography and the Armenian Massacres,” Middle Eastern Studies 12, 1 (1976): 99-107.

91 Lawrence L. Langer, Using and Abusing the Holocaust (Bloomington: Indiana University Press, 2006), 97-111.

92 For example, Tehlirian's emotional testimony is told in great detail, but only to be revealed, as an aside, to be a false testimony, in Ihrig, Justifying Genocide, 263. Others do not even bother to mention that it is imagined, such as in Sévane Garibian, "Commanded by My Mother's Corpse': Talaat Pasha, or the Revenge Assassination of a Condemned Man," Journal of Genocide Research 20, 2 (2018): 220-35; Power, "Problem from Hell," 1-16. For a more detailed analysis of this silence over Tehlirian's false testimony, see Christopher Gunn, "Getting Away with Murder: Soghomon Tehlirian, ASALA, and the Justice Commandos, 1921-1984," in M. Hakan Yavuz and Feroz Ahmad, eds., War and Collapse: World War I and the Ottoman State (Salt Lake City: University of Utah Press, 2016), 910-11. 
have what one might call today a post-traumatic stress disorder, as he suffered from seizures, anxiety attacks, and hallucinations. The defense counsel argued that Tehlirian was, according to $\S 51$ of criminal law, "at the time of the commission of the act [...] in a state of unconsciousness or disturbance of the mental processes due to illness," which would free him from culpability. ${ }^{93}$ As Turkish scholars continue to insist, the medical testimony was ambivalent and did not necessarily support these claims. ${ }^{94}$ "Tehlirian, who upheld the moral order of mankind, was classified as insane, incapable of discerning the moral nature of his act," wrote Raphael Lemkin in his autobiography, because the logic of revenge is morally corrupt from a legal perspective. ${ }^{95}$

Even if the avenger can demonstrate authentic motivation and lack of culpability, the human sacrifice should better serve the greater good of humanity if it is to be legitimized. In the final defense of Tehlirian, his attorney, Gordon, underlined the moral and historical significance of the case to the members of the jury: “As I've already told you, jurors: Your verdict will be remembered probably for thousands of years due to this vicious crime." 96 The "language of barbarism and humanism" was used in Tehlirian's defense to underline the extralegal imperative for morality. ${ }^{97}$ Tehlirian's trial resulted in his sensational acquittal by the jury on grounds of his traumatized mental and medical condition. ${ }^{98}$ After the verdict, his supporters applauded and congratulated their hero before hurrying him out of the building to a waiting car. Tehlirian left the country shortly thereafter. Talat's widow and the Young Turk community were shocked. ${ }^{99}$

Revenge without punishment encourages imitation and repetition. On 17 April 1922, Tehlirian's fellow Nemesis hitmen in Berlin assassinated Talat's two other accomplices, Dr. Bahaeddin Şakir and Cemal Azmi, in front of their

93 Benjamin Carter Hett, Death in the Tiergarten: Murder and Criminal Justice in the Kaiser's Berlin (Cambridge: Harvard University Press, 2004), 195.

94 Șeref Ünal, Der Prozess gegen Salomon Teilirian: Das Talaat-Pascha-Attentat (Berlin 2.-3. Juni 1921) (Ankara: Justitia Fundamentum Regnorum, 2007), 42-43.

95 Donna-Lee Frieze, Totally Unofficial: The Autobiography of Raphael Lemkin (New Haven: Yale University Press, 2013), 20. It is common for sympathetic works of history to project the young law student Lemkin as one of the people in the courtroom, witnessing this historic verdict. For example, Marc David Baer, Sultanic Saviors and Tolerant Turks: Writing Ottoman Jewish History, Denying the Armenian Genocide (Bloomington: Indiana University Press, 2020), viii. In fact, though Lemkin followed the news about Tehlirian's trial closely, he was at the University of Lemberg (today Lviv in Ukraine). John Cooper, Raphael Lemkin and the Struggle for the Genocide Convention (Basingstoke: Palgrave Macmillan, 2008), 15.

96 Wegner, Der Prozeß Talaat Pascha, 123.

97 Dean, Moral Witness, 59.

98 Similarly, Armenian assassin Misak Torlakyan, who killed the former Azerbaijani minister of interior Behbud Khan Javanshir in İstanbul on 18 July 1921, was acquitted by the British military tribunal due to his epilepsy. Eyal Ginio, "Debating the Nation in Court: The Torlakian Trial (Istanbul, 1921)," Armenian Review 55, 1-2 (2015): 1-16.

99 Denker, Talat Paşa'nın Son Günleri, 187-89. 
wives and Talat's widow. ${ }^{100}$ Yet, this time the avengers chose to flee the law, as revenge had become more important than a public certification of justice. The flight of these hitmen, however, limited their later heroization compared to that of Tehlirian.

\section{UNDERNEATH THE SILENCE: SUSTAINING GRIEVANCES}

The final settlement of the First World War in 1923 brought a bitter end to the Armenian Question. The new Republic of Turkey emerged with regained sovereignty in place of Ottoman Anatolia, but the newly founded Republic of Armenia in the Caucasus had already been swallowed up by the Soviet Union. Hundreds of thousands of Armenian survivors were displaced across a worldwide diaspora. While there was more or less silence about what happened to Armenians in 1915, commemorations of martyrdom and revenge sustained grievances. In post-conflict societies, heroes consolidate collective identities. ${ }^{101}$ As Berel Lang reminds, acts of revenge and narratives of vengeance "have had a more substantial influence in shaping collective memory of the Shoah than has so far been recognized." 102 Beyond seeking justice, vengeance and revenge contribute to the construction of post-victimhood identity by reclaiming agency and violence. $^{103}$

Heroization is contingent and context dependent. After 1921, Tehlirian had first traveled to the United States "where he was feted as a hero." ${ }^{104}$ At banquets and community gatherings, old women would kiss his hand and men of all ages would celebrate him as a national hero. ${ }^{105}$ Later he would practically disappear, changing his name and settling in Belgrade. Meanwhile, there was little room for Talat's commemoration in Atatürk's Turkey. Yet, whenever the Armenian Question reemerged as a threat to Turkey's raison d'état, Talat's martyrdom was reanimated in memories. In its early years, the young republic's leadership was obsessed with conspiracy theories about political assassins, in which Armenians

100 Arshavir Shiragian, The Legacy: Memoirs of an Armenian Patriot, Sonia Shiragian, ed. (Boston: Hairenik Press, 1976), 169-81.

${ }^{101}$ Giesen, Triumph and Trauma. On heroes and collective identities, see also Olmo Gölz, "Heroes and the Many: Typological Reflections on the Collective Appeal of the Heroic: Revolutionary Iran and Its Implications,” Thesis Eleven 165, 1 (2021): 53-71.

102 Berel Lang, "Holocaust Memory and Revenge: The Presence of the Past," Jewish Social Studies 2, 2 (1996): 1-20, 3.

103 Shai Lavi, “The Jews Are Coming': Vengeance and Revenge in Post-Nazi Europe,” Law, Culture and the Humanities 1, 3 (2005): 282-301.

104 Derogy, Resistance and Revenge, 103.

105 Edward Alexander met Tehlirian as a young boy in 1925 at a church gathering in his honor; see his A Crime of Vengeance: An Armenian Struggle for Justice (New York: The Free Press, 1991), 2056. See also Alexander's video message in the online panel discussion, "New Perspectives on the Shooting of Talaat Pasha in Berlin 1921: After 100 Years," National Association for Armenian Studies and Research, 15 Mar. 2021, https://youtu.be/kfw905xeiiU (last accessed 12 May 2021). 
featured constantly. ${ }^{106}$ After 1926, the surviving dependents of Talat and the other Young Turk leaders killed by Armenian avengers received confiscated Armenian property and a dependent's pension from the state as compensation. ${ }^{107}$ This decision was framed in a vengeful speech in parliament as "a strong warning message to assassins: you may execute a Turk through an assassination! But we will raise his offspring with your money so that tomorrow, he will gouge out your eye and break your head." 108

The martyr's body is an important site of repetitive commemoration in different contexts. When Talat's widow requested that the Turkish government arrange for the return of his remains to his homeland, President Mustafa Kemal (Atatürk) told her personally that Talat's remains could not simply be brought back to Turkey, implying that doing so would bring back the Armenian Question from oblivion. ${ }^{109}$ Talat received a second funeral in May 1930, when he was buried at the Muslim cemetery in Berlin. ${ }^{110}$ During the Second World War, in 1943, the Nazi regime offered to transport Talat's remains by train to İstanbul as a goodwill gesture to still-neutral Turkey, which was under pressure to take sides. A Turkish newspaper announced that "Germany has expressed its respect toward the martyr." 111 On 25 February 1943, there was a great military ceremony at his funeral. Talat was buried at the Monument of Eternal Liberty (Hürriyet-i Ebediye Abidesi) in Șişli, İstanbul, where other Young Turk "heroes of liberty" are buried. ${ }^{112}$ Talat's funeral ceremony officially rehabilitated him in Kemalist Turkey, and he was celebrated in the press as the "symbol of Turkish patriotism." "113 When the Turkish Hearths Society was re-opened in 1949, its nationalist members even considered building a Talat Pasha mausoleum, but it was never realized. ${ }^{114}$ One of Talat's loyal followers from the CUP, Celal Bayar,

106 Ramazan H. Öztan, "Republic of Conspiracies: Cross-Border Plots and the Making of Modern Turkey," Journal of Contemporary History 56, 1 (2021): 55-76, 58.

107 For the relevant documents from 1927 to 1940, see Murat Bardakçı, ed., Ittihadçı'nın Sandığ : Ittihat ve Terakki Liderlerinin Özel Arşivlerindeki Yayınlanmamış Belgeler ile Atatürk ve İnönü Dönemlerinde Ermeni Gayrimenkulleri Konusunda Alınmış Bazı Kararlar (Ankara: Türkiye İș Bankası Yayınları, 2013), 27-56. For more context, see Taner Akçam and Ümit Kurt, The Spirit of the Laws: The Plunder of Wealth in the Armenian Genocide (New York: Berghahn Books, 2015), 168-72.

${ }^{108}$ Quoted in Soner Çağaptay, Islam, Secularism, and Nationalism in Modern Turkey: Who Is a Turk? (London: Routledge, 2006), 37; Ekmekçioğlu, Recovering Armenia, 96.

109 Bardakç1, "Interview with Hayriye Talat Bafralı, October 1982," 223-25.

110 Berliner Börsen-Zeitung, 10 May 1930, evening issue, archive of the Zentrum Moderne Orient, Berlin, Gernard Höpp Private Papers, file 07/03/047.

111 Tasvir-i Efkar, 18 Feb. 1943, quoted in Robert W. Olson, "The Remains of Talat: A Dialectic between Republic and Empire," Die Welt des Islams 26, 1 (1986): 46-56, 47.

112 Edhem Eldem, Death in Istanbul: Death and Its Rituals in Ottoman-Islamic Culture (İstanbul: Ottoman Bank Archives and Research Centre, 2005), 276-79.

113 Quoted in Olson, "Remains of Talat," 52. See also Thomas de Waal, Great Catastrophe: Armenians and Turks in the Shadow of Genocide (Oxford: Oxford University Press, 2015), 102.

114 Talin Suciyan, The Armenians in Modern Turkey: Post-Genocide Society, Politics and History (London: I. B. Tauris, 2016), 166. 
was president of the Republic from 1950 to $1960 .{ }^{115}$ Despite all this, Talat never became a broadly commemorated popular hero in Turkey. Starting in the 1950s, a new wave of Islamist publications emerged that openly vilified Talat in antisemitic conspiracy theories. These accused him of being a Jacobin, Freemason, and Zionist conspirator against Sultan Abdülhamid II, the hero of the new Muslim-conservative generations who felt alienated by the secularism of the republic that had started with Young Turks like Talat. ${ }^{116}$ As a result, the Talat's occasional heroization enjoyed limited resonance among the conservative masses.

Unlike martyrs, avengers can manage their own celebration to a certain degree in their lifetime, but they cannot fully escape their heroic reputation and its obligations. Tehlirian returned from oblivion when he immigrated back to the United States in 1956 and was rediscovered by the Armenian diaspora as a lost hero. ${ }^{117}$ According to his son, however, he was reluctant to play the hero's role: "He would give patriotic speeches but he really never liked to talk of what happened." 118

After death, just like martyrs, the avenger's posthumous body can provide salvation for the commemorating community, because it, too, endured but overcame unjust victimization. Tehlirian died in 1960, ${ }^{119}$ and in 1969 a monumental gravestone was erected at the Ararat Cemetery in Fresno, California (it was renovated in 1995). A statue of an eagle attacking a snake sits on top of it, and for many Armenians it continues to serve as the locus of commemorations and collective healing. ${ }^{120}$

\section{COMBATIVE COMMEMORATION: NEW AVENGERS AND MARTYRS}

The Armenian Genocide was brought back to international public attention in 1965 with commemorations of its fiftieth anniversary, breaking the silence of the

\footnotetext{
115 Until his death in 1986, Bayar considered Talat to be his "boss." Murat Bardakç1, ed., Talat Paşa’nın Evrak- Metrukesi: Sadrazam Talat Paşa’nın Özel Arşivinde Bulunan Ermeni Tehciri Konusundaki Belgeler ve Hususi Yazlşmalar (İstanbul: Everest, 2009), 185.

116 This was most prominent in Necip Fazıl Kısakürek, Ulu Hakan: II. Abdülhamiid Han (İstanbul: Büyük Doğu Yayınları, 1965).

117 Tim Neshitov, "Der Adler: Rächer für Völkermord an Armeniern,” Süddeutsche Zeitung, 20 Mar. 2015, https://www.sueddeutsche.de/politik/voelkermord-der-adler-1.2442261.

118 Robert Fisk, "My Conversation with the Son of Soghomon Tehlirian: The Man Who Assassinated the Organiser of the Armenian Genocide," Independent, 20 June 2016, http://www. independent.co.uk/voices/robert-fisk-armenian-genocide-conversation-son-of-soghomon-tehlirianmehmet-talaat-pasha-a7091951.html (last accessed 12 May 2021).

119 For an obituary of Tehlirian (under his assumed name "Saro Melikian"), see "Saro Melikian, Armenian Hero," New York Times, 26 May 1960: 33. There was series of articles in Armenian Review from 1960 to 1962, discussed in Christopher Gunn, "Secret Armies and Revolutionary Federations: The Rise and Fall of Armenian Political Violence, 1973-1993" (PhD diss., Florida State University, 2014), 26-27.

${ }^{120}$ Sarah Vartabedian, "Commemoration of an Assassin: Representing the Armenian Genocide" (MA thesis, University of North Carolina, 2007), 9.
} 
first generation of survivors. ${ }^{121}$ The fact that Armenians found themselves on both sides of the Cold War's iron curtain — and Turkey's status as a loyal NATO ally-complicated international recognition. In this dilemma, the legacy of Tehlirian as a heroic avenger transcended rituals and sites of commemoration and became a model for political radicalism in the 1970s. In 1973, a seventyseven-year-old Armenian-American named Gourgen Yanikian gunned down two Turkish diplomats in a hotel in Los Angeles. In his testimony, Yanikian narrated his own biography in a way conspicuously like Tehlirian's life. After the murder, Yanikian, too, had wanted to publicize his trial to call attention to the Armenian Genocide, though he was found guilty of murder. Without a doubt, Tehlirian was Yanikian's hero and role model. ${ }^{122}$ Yanikian was alone, but his acts inspired a new wave of terrorist attacks against Turkish diplomats and officials. A post-genocidal generation of diaspora Armenians, located mostly in civil warstruck Lebanon and the United States, founded armed groups such as the Armenian Secret Army for the Liberation of Armenia (ASALA), the Justice Commandos of the Armenian Genocide (JCAG), and the Armenian Revolutionary Army (ARA). The terrorist attacks carried out by these groups took the lives of over thirty Turkish officials, their relatives, and many others. ${ }^{123}$ New avengers created new martyrs. The five ARA terrorists killed in the 1983 bombing of the Turkish embassy in Lisbon have been commemorated by the Armenian community in the United States as "martyrs." 124 Although Armenian and Turkish narratives are eager to draw a heroic or villainous continuity reaching back to Tehlirian and beyond, Armenian terrorist attacks against Turkish diplomats should be read in the global context of the Cold War during the 1970s and 1980s. ${ }^{125}$ Yet, historical references to Tehlirian's assassination of Talat also shaped the framing of terrorism in this period. The trials of Armenian terrorists were meant to replicate the public impact of Tehlirian's trial. ${ }^{126}$ These militant Armenian organizations and their followers celebrated Tehlirian as their national hero and justified their own violence in phrases such as, "The avenging arm of

121 Waal, Great Catastrophe, 126-48.

122 Gunn, "Getting Away with Murder," 906. For more information on Yanikian's references to Tehlirian and contradictions in his testimony, see Gunn, "Secret Armies," 89-96.

123 Michael M. Gunter, Armenian History and the Question of Genocide (New York: Palgrave Macmillan, 2011), 62-72; Vicken Cheterian, Open Wounds: Armenians, Turks and a Century of Genocide (London: Hurst, 2015), 123-31.

${ }^{124}$ See the examples listed in Heath W. Lowry, "Nineteenth and Twentieth Century Armenian Terrorism: 'Threads of Continuity,", in International Terrorism and the Drug Connection (Ankara: University of Ankara Press, 1984), 79-81.

${ }^{125}$ Some Armenian Genocide scholars lump together Operation Nemesis and JCAG/ASALA as a continuum of vengeance. For instance, Tessa Hofmann, "An Eye for an Eye: The Assassination of Talaat Pasha on the Hardenbergstrasse in Berlin," in Huberta von Voss, ed., Portraits of Hope: Armenians in the Contemporary World (New York: Berghahn, 2007), 297.

126 Gunter, Armenian History, 62. 
Talaat's assassins strike again." 127 In 1974, the ARF started to organize a new Armenian celebration day on 15 March, "Avenger's Day," with reenactments of the assassination and the trial. ${ }^{128}$ The trial's proceedings have been re-enacted in Armenian theatre plays and feature films ever since then. ${ }^{129}$ Hampig Sassounian, who assassinated the Turkish consul general in Los Angeles in 1982, is known to have posed for a photo in front of Tehlirian's gravestone. ${ }^{130}$ Over time, the stigma of terrorism became detrimental to the cause of international recognition of the Armenian Genocide. ${ }^{131}$

Faced with external pressures related to the rise of international awareness of the Armenian Genocide, and especially as a reaction to Armenian terrorism, in the 1970s and 1980s official state discourse in Turkey turned from silencing the past to countering genocide narratives with a new proactive discourse. ${ }^{132}$ The killing of Turkish diplomats and their relatives was framed in the same trope of martyrdom as found in the Talat-Tehlirian complex. ${ }^{133}$ The Armenian terrorism of this era was meant to remind Turks about the sacrifice of their statesmen, the ever-present threat of Armenian terrorism and propaganda, and the unrecognized suffering of Turks in international politics. ${ }^{134}$ Talat's heroization as a martyr was revived, and it was during this period that many districts, streets, schools, and mosques, and other public spaces all over Turkey were named after him. ${ }^{135}$ In 1986, the national television channel TRT produced and broadcasted a

127 Khachig Tölölyan, "Cultural Narrative and the Motivation of the Terrorist," Journal of Strategic Studies 10, 4 (1987): 217-33, 225.

128 Gunn, "Secret Armies," 139.

129 For the Armenian-American film Assignment Berlin (1982), see: https://www.imdb.com/title/ tt0388744/ (last accessed 12 May 2021). There have been several theater plays and reenactments. For a recent example, see Yeghishe Hajakian, "Tehlirian Trial Comes Alive," Armenian Mirror-Spectator, 14 May 2015, https://mirrorspectator.com/2015/05/14/tehlirian-trial-comes-alive/ (last accessed 12 May 2021). See also Bașak Ertür, "Spectacles and Spectres: Political Trials, Performativity and Scenes of Sovereignty" (PhD thesis, University of London, 2015), 127-63.

130 Maxim Gauin, "L'assassin et menteur Soghomon Tehlirian: un modèle récurrent pour le terrorisme arménien contemporain,” Blogspot: Sources sur la question arménienne, 15 Mar. 2021, http:/question-armenienne.blogspot.com/2021/03/lassassin-et-menteur-soghomon-tehlirian.html (last accessed 12 May 2021).

131 Waal, Great Catastrophe, 149-77.

132 Doğan Gürpınar, "The Manufacturing of Denial: The Making of the Turkish 'Official Thesis' on the Armenian Genocide between 1974 and 1990," Journal of Balkan and Near Eastern Studies 18, 3 (2016): 217-40; Jennifer M. Dixon, Dark Pasts: Changing the State's Story in Turkey and Japan (Ithaca: Cornell University Press, 2018), 44-66.

133 Fatma Müge Göçek, Denial of Violence: Ottoman Past, Turkish Present, and Collective Violence against the Armenians, 1789-2009 (Oxford: Oxford University Press, 2015), 429.

134 See the "martyrs' day" note on the Turkish Ministry of Foreign Affairs, http://www.mfa.gov. tr/18-mart-sehitler-gunu_nde-disisleri-sehitliginde-duzenlenecek--toren-hk-bilgi-notu_en.en.mfa (last accessed 12 May 2021).

135 See Le Monde, 24 Apr. 1981, cited in Jan Kirakossian, The Armenian Genocide: The Young Turks before the Judgment of History (Madison: Sphinx Press, 1992), 227. For a list of all places carrying the name "Talat Paşa" or "Talatpașa," see: http://www.aga-online.org/worship/talat-pasha. php?locale=de (last accessed 12 May 2021). These street names are particularly offensive to Armenians. Survivors demand they be changed. Waal, Great Catastrophe, 252. 
miniseries Duvardaki Kan ("The blood on the wall"), which dramatized Talat's assassination by Tehlirian. ${ }^{136}$ As part of this proactive approach, Talat's bloodstained shirt was put on display at the Turkish Military Museum in İstanbul, similar to Franz Ferdinand's shirt hung in the Austrian Military Museum after he was killed by Serbian assassins.

\section{CONVERGING AND DIVERGING COMMEMORATIONS}

A brief moment of societal opening in Turkey in the mid-2000s enabled some critical engagement and ethical recognition of what happened to Armenians in 1915. ${ }^{137}$ In 2007, amidst this moment of reconciliation, one of its main protagonists, the Turkish-Armenian journalist Hrant Dink, was tragically assassinated. The cult of martyrdom conditions revenge. Dink's assassination was a violent manifestation of the Talat-Tehlirian complex. Dink's seventeen-year-old, ultranationalist murderer Ogün Samast, who was connected to conspiratorial networks within the security forces, shot him in the back of his head in broad daylight on a main street in İstanbul, thus re-performing Tehlirian's act. Ultranationalist officials and movements did not hesitate to celebrate Samast as their "hero" and condemn Dink as a "traitor." In return, Dink's supporters started to commemorate Dink as their "martyr" in hopes of breaking the cycle of denial and resentment in Turkish-Armenian relations. ${ }^{138}$ Historians also drew connections to 1921. Genocide scholar Taner Akçam pointed out that Dink's murder was framed by its accomplices and supporters as a "revenge" for Talat's assassination; Murat Bardakçı, a popular historian and the curator of Talat's private archive, pointed out that an Operation Nemesis-like secret organization lay behind Dink's assassination, but that Samast, like Tehlirian, claimed to be a lone-wolf assassin. ${ }^{139}$ In a vicious circle of contention, Talat and Tehlirian remained at the center of legitimizing violence in Turkish-Armenian relations.

Beyond expressing their longing for salvation, those who honor martyrs and avengers can utilize their commemorations to compete with the opposing groups. Hence Talat and Tehlirian continued to play symbolic roles in overtly

136 The screenplay was written by a popular historian of Turkey, who also wrote one of the major books of the time that denied the Armenian Genocide. Mim Kemal Öke, The Armenian Question: 1914-1923 (Oxford: Rustem \& Brother, 1988). For the mini-series, see https://www.imdb.com/title/ tt5524310/ (last accessed 12 May 2021).

137 For more on that context, see Dixon, Dark Pasts, 77-90.

138 On Dink's commemoration as a "martyr" (as opposed to a "traitor"), see Fatma Müge Göçek, "The 2007 Assassination of Hrant Dink through the Lenses of History, Memory and Emotions," Zeitschrift für Religions- und Geistesgeschichte 70, 2 (2018): 149-63, 157-58.

139 Taner Akçam, “Talat Paşa'nın İntikamı Alınmıștır...," Taraf, 23 Jan. 2012, http://www.agos. com.tr/tr/yazi/407/taner-akcam-talat-pasanin-intikami-alinmistir (last accessed 12 May 2021); Murat Bardakçı, “Nemesis’in İșlediği Cinayetlerde de Karar Aynıydı: Örgütü Bulamadılar!” HaberTürk, 22 Jan. 2012, https://www.haberturk.com/yazarlar/murat-bardakci/708373-nemesisin-isle digi-cinayetlerde-de-karar-ayniydi-orgutu-bulamadilar (last accessed 12 May 2021). 
contentious commemorations. Reacting to growing international recognition of the Armenian Genocide, Turkish nationalists began in the mid-2000s to commemorate Talat every 15 March at his grave. ${ }^{140}$ There is also a competitive aspect of commemoration, as some Turks find the desolate situation of Talat's grave in İstanbul a disgrace compared to the monumental gravestone of Tehlirian in California. ${ }^{141}$ With the approach of the centennial of the Armenian Genocide in 2015, Talat became the most visible face of genocide denialism. Controversial campaigns were spearheaded by the notorious "Talat Pasha Committee" (Talat Pașa Komitesi), a major "reputational entrepreneur" in the Talat-Tehlirian complex. ${ }^{142}$ The Committee propagated the claim that "the Armenian Genocide is an international lie."143 They often referred to Talat as a "revolutionary martyr" who was killed by Armenian partisans because "he never bowed down to colonialism." 144 Along with the legal help of the Turkish state, the Committee effectively utilized international law for Turkish propaganda purposes during the Perinçek v. Switzerland case at the European Court of Human Rights in 2015, where Maoist-turned-ultranationalist Doğu Perinçek was eventually acquitted for publicly denying the Armenian Genocide, which is legally prohibited in Switzerland. ${ }^{145}$

Tehlirian, too, played a symbolic role in the more overtly nationalist commemorations of the centennial. The Armenian Republic made attempts to move his remains to a new and more monumental tomb, in Armenia, but his family denied the request. ${ }^{146}$ A statue of Tehlirian erected in Maralik in Armenia caused a great deal of controversy in Turkey because its original design had him holding a gun and with one foot on Talat's severed head. ${ }^{147}$ In Marseilles, France, a

140 See, for instance, http://www.hurriyet.com.tr/talat-pasa-mezari-basinda-anildi-17277624 (last accessed 12 May 2021); http://www.hurriyet.com.tr/talat-pasa-mezari-basinda-anildi26286951 (last accessed 12 May 2021).

141 The neglect of the Eternal Liberty cemetery is noted also in Laure Marchand and Guillaume Perrier, Turkey and the Armenian Ghost: On the Trail of the Genocide (Montreal: McGill-Queen's University Press, 2015), 113-14. See also the photos and comments in the appendix of Bardakç1, Talat Paşa'nın Evrak-ı Metrukesi.

142 For reputational entrepreneurs, see Gary A. Fine, "Reputational Entrepreneurs and the Memory of Incompetence: Melting Supporters, Partisan Warriors, and Images of President Harding," American Journal of Sociology 101, 5 (1996): 1159-93.

143 The homepage of this organization is no longer available, though its last archived version from March 2016 is available at https:/web.archive.org/web/20160313010003/http://talatpasakomitesi. com/ (last accessed 12 May 2021). See also Marchand and Perrier, Turkey and the Armenian Ghost, 114.

${ }^{144}$ See the news report on Talat Pasha's commemoration on 15 Mar. 2013, on Ulusal Kanal, https://youtu.be/LTY9n1FZqTM (last accessed 12 May 2021).

145 On the Perinçek v. Switzerland case, see Alexis Demirdjian, “A Moving Defence: The Turkish State and the Armenian Genocide," Journal of International Criminal Justice 16, 3 (2018): 501-26, 522-23; Bașak Ertür, "Law of Denial," Law and Critique 30, 1 (2019): 1-20.

146 Neshitov, "Der Adler."

147 Mehmet Oğuzhan Tulun, "Armenia and the Veneration of Terrorists-II," Avim 21 (16 Sept. 2019), https://avim.org.tr/en/Analiz/ARMENIA-AND-THE-VENERATION-OF-TERRORISTS-II (last accessed 12 May 2021). 
square was named after Tehlirian, "Défenseur de Peuple Arménien," in April 2017. ${ }^{148}$ Meanwhile, graphic novels introduced the story of Operation Nemesis to a new generation of diaspora Armenians. ${ }^{149}$

The cult of martyrdom typically relies on the unity of the community, but this is not the case for Talat, whose commemoration as a martyr is contested from within. He is still less popular, and even disliked among Turkey's conservative majority, and especially among Islamists. This becomes unmistakably clear when Talat is compared to his fellow Young Turk leader Enver Pasha, who is celebrated for his pan-Turkism and pan-Islamism by conservative nationalists (but disliked by Kemalists), or to Abdülhamid II, whose Islamized personality cult rose immensely after the rise to power of the Justice and Development Party. ${ }^{150}$ Islamists villainize Talat for dethroning Abdülhamid and hence opening the way for the collapse of the Ottoman Empire. TRT's popular TV series Payitaht Abdülhamid ("Capital Abdülhamid" [sic]) is, however, a recent attempt to rehabilitate Talat for Muslim-conservative viewers at a time when President Recep Tayyip Erdoğan is trying to build a united Islamist-ultranationalist front. Though he is still among the villains, Talat is depicted in the series rather favorably as an Ottoman-Muslim patriot who was lured into an international conspiracy against the great sultan led by Freemasons and Jews. ${ }^{151}$ Beyond denialism, Talat's contentious narratives within Turkey's wide spectrum of nationalists illustrate that his heroization is contingent on how groups make sense of Turkey's transition from empire to republic.

One post-heroic intervention was voiced by none other than Tehlirian's son, who rejects the heroization of his father as an avenger. In a 2015 interview with a German newspaper, he said: "How can a murderer be a hero? I am probably a bad Armenian. But to make it clear: my father never saw himself as a hero."152 "The Armenians keep trying to tip things out of the grave," the same son said in another interview. "It's three generations ago. It's history. Everyone killed a lot of

\footnotetext{
148 “Soghomon Tehlirian Square Inaugurated in Marseille," Armenian Mirror-Spectator, 27 Apr.

2017, https://mirrorspectator.com/2017/04/27/soghomon-tehlirian-square-inaugurated-in-mar seille/ (last accessed 12 May 2021).

149 See Jean-Jacques Varoujean, Jean-Blaise Djian, and Paolo Cossi, Mission spéciale: Némésis (Alfortville: Éditions Sigest, 2014); Josh Blaylock and Hoyt Silvam, Operation Nemesis: A Story of Genocide and Revenge (Chicago: Devil's Due Entertainment, 2015).

${ }^{150}$ Olivier Bouquet, "Les Cemal et les Enver: Infidélité généalogique, glorification nationale et mémoire du génocide arménien (Turquie, 1915-2015),"Vingtième Siècle: Revue d'histoire 3, 131 (2016): 93-108, https://www.cairn.info/revue-vingtieme-siecle-revue-d-histoire-2016-3-page93.htm; Edhem Eldem, "Sultan Abdülhamid II: Founding Father of the Turkish State?” Journal of the Ottoman and Turkish Studies Association 5, 2 (2018): 25-46.

151 See, for instance, https://youtu.be/dlAzCx7eqSU (last accessed 12 May 2021).

152 Neshitov, "Der Adler." Another son of Tehlirian, interviewed in Belgrade in 1978, was more "proud" about his father's posthumous reputation. Robert P. Jordan, "The Proud Armenians," National Geographic 153, 6 (June 1978): 846-73, 862.
} 
people. [...] I never remember my father saying one bad word about the Turks. He just wanted to live his life in peace."153

CONCLUSION: POST-HEROIC THOUGHTS ON THE MARTYR-AVENGER COMPLEX

The Talat-Tehlirian complex contributed considerably to the existing contentious narratives of the Armenian Genocide by providing heroic configurations of martyrdom and revenge. As such, Talat and Tehlirian, standing in for all Turks and all Armenians collectively, continue to compete in the heroic imaginaries of new generations and further complicate Turkish-Armenian relations. In anticipation of the centennial of the assassination on 15 March 2021, Tehlirian and Talat's heroizations reached new heights, once again, in social media. ${ }^{154}$

As a martyr, Talat is imagined by his followers as a heroic statesman in times of triumph and tragedy who became a martyr at the hands of an unworthy perpetrator, a minion of a greater villain. In Turkey, the concept of martyrdom is closely associated with the raison d'état of the state. ${ }^{155}$ Hence, the heroization of Talat is intertwined with the historical sociology of Turkey's nation-state formation, which is imagined as a self-sacrificial struggle against great empires and local traitors. As an avenger, Tehlirian combines the human need for salvation after survival with an active commitment to honor and avenge the martyrs. Since all genocide victims are considered martyrs, Armenian commemorations exhibit strong references to notions of martyrdom in both religious and nationalist discourse, which contributes to emotions of grievance and desires for vengeance against Turks. ${ }^{156}$ Although triumphant in his heroic deed, Tehlirian remains a

153 Fisk, "My Conversation."

154 Among many others, the YouTube channel "Tales of Truth: The Authorized Soghomon Tehlirian Story" is worth mentioning. For instance, during a feature, 27 Oct. 2020, on how Armenian soldiers in the Nagorno-Karabakh conflict of summer 2020 sang a ballad about Tehlirian, the channel's host calls Tehlirian "a hero's hero" and Talat "a larger terrorist than Adolf Hitler," https://youtu.be/oHF9n98BgeQ (last accessed 12 May 2021). The way in which Turkish nationalists boosted the heroization of Talat in social media is discussed in Alin Ozinian, "Hero, Founder, or Criminal? Talaat Is Still Alive and Well in Turkey," Turkish Minute, 28 Apr. 2021, https://www. turkishminute.com/2021/04/28/hero-founder-criminal-talat-is-still-alive-and-well-in-turkey/ (last accessed 12 May 2021).

${ }^{155}$ For the historical semantics of martyrdom in Turkey, see Alp Yenen, "Legitimate Means of Dying: Contentious Politics of Martyrdom in the Turkish Civil War (1968-1982)," Bethemoth-A Journal on Civilisation 12, 1 (2019): 14-34, 16-18, https://doi.org/10.6094/ behemoth.2019.12.1.1004.

156 Khachig Tölölyan, "Martyrdom as Legitimacy: Terrorism, Religion and Symbolic Appropriation in the Armenian Diaspora," in Paul Wilkinson and Alasdair M. Stewart, eds., Contemporary Research on Terrorism (Aberdeen: Aberdeen University, 1987), 89-103; Khachig Tölölyan, "Terrorism in Modern Armenian Political Culture," Terrorism and Political Violence 4, 2 (1992): 8-22. See also the autobiographical narrative of a post-genocidal Armenian wedding ceremony, where "the smells of martyrs' souls" is mentioned, as quoted in Lerna Ekmekcioglu, "A Climate for Abduction, a Climate for Redemption: The Politics of Inclusion during and after the Armenian Genocide," Comparative Studies in Society and History 55, 3 (2013): 522-53, 550. For more patriotic references to martyrdom, see Ekmekçioğlu, Recovering Armenia, 49. 
tragic figure in the continued struggle for the recognition of the Armenian Genocide.

The Talat-Tehlirian complex has theoretical implications that go beyond the idiosyncrasies of Turkish-Armenian relations. As a martyr-avenger complex, it explains historical and heroic configurations of martyrdom and revenge in postconflict societies. Martyrs and avengers are relational social constructions that can mutually condition each other in specific historical circumstances. Not all heroes are granted sacralization, but martyrs and avengers are, because they offer salvation through dying and killing. ${ }^{157}$ Since martyrdom and revenge involve violence and sacrifice, their followers must explain to their own social groups the act of death in terms of salvation and frame it for the broader public in recognizable terms of justice or injustice. Given that martyrs and avengers are ambiguous archetypes within the imaginary field of the heroic, which can feature notions of heroes, villains, perpetrators, and victims all at once, they create a rich but recognizable template for various contentious narratives. The frequent juxtaposition of heroic configurations against one another in contentious politics indicates that people make sense of political actions according to how they imagine their heroes and villains would act against each another. ${ }^{158}$ In social interactions, both martyrdom and revenge require the continued commitment of social groups through collective oaths, rituals, and performances. ${ }^{159}$ Once internalized in the political memory of opposing groups, the martyr-avenger complex, as a mutual framework of sensemaking, demands solidarity, sustains grievances, and sacralizes violence against the Other.

The martyr-avenger complex equates reconciliation to a betrayal of the past. This has consequences for contentious narratives of heroic configurations: "One side's betrayal is the other side's heroism." 160 Therefore, moments of reconciliation can encourage renewed grievances and retaliations. According to Giesen, "The vicious circle of violence and revenge has to be interrupted by special institutions instead of waiting for its end to result just from mutual exhaustion." "161 How such "special institutions" should intervene on behalf of the historical recognition of the Armenian Genocide and the reconciliation in

157 Felix Heinzer, Jörn Leonhard, and Ralf v. d. Hoff, eds., Sakralität und Heldentum (Würzburg: Ergon Verlag, 2017).

158 James M. Jasper, Protest: A Cultural Introduction to Social Movements (Cambridge: Polity Press, 2014), 91-97; Nicole Doerr, "Memory and Culture in Social Movements," in Britta Baumgarten, Priska Daphi, and Peter Ullrich, eds., Conceptualizing Culture in Social Movement Research (London: Palgrave Macmillan, 2014), 210-13.

159 Chris Moffat, "Politics and the Work of the Dead in Modern India," Comparative Studies in Society and History 60, 1 (2018): 178-211, 210. On the political anthropology of oaths, see Keith Brown, Loyal unto Death: Trust and Terror in Revolutionary Macedonia (Bloomington: Indiana University Press, 2013), 70-97.

160 Jasper, Protest, 95-96.

161 Giesen, Triumph and Trauma, 152. Similar thoughts are expressed in Girard, Violence and the Sacred, 21. 
Turkish-Armenian relations is still a matter of discussion. ${ }^{162}$ One small but critical step toward reconciliation would be a post-heroic parting with the Talat-Tehlirian complex after one hundred years of its haunting.

\begin{abstract}
The assassination of Talat Pasha by Soghomon Tehlirian on 15 March 1921 in Berlin, as well as Tehlirian's trial and acquittal on 2-3 June 1921, have contributed to the formation of conflicting legacies of the Armenian Genocide. Though minuscule in terms of violence and legal ramifications, these events and their reimagination in contentious narratives have shaped a dominant prism of sensemaking in Turkish-Armenian relations. In the imagination of rival groups, Talat and Tehlirian compete for the very same normative categories of hero and victim at once and each are demonized as a villain and perpetrator. Moreover, it is each figure's embodiment of martyrdom and revenge that explains why their heroizations have proved so enduring and effective across time and space. This mutual framework of sensemaking, which I call the Talat-Tehlirian complex, ultimately denies the chances of historical reconciliation. In terms of its theoretical implications, this case study explains how a martyr-avenger complex can continuously demand solidarity, sustain grievances, and sacralize violence in post-conflict societies. Based on a thick description of what happened in Berlin in 1921 and its contentious narratives across different generations, this paper calls for a transition to a post-heroic age in Turkish-Armenian relations.
\end{abstract}

Key words: Armenian Genocide, assassination, heroes, villains, perpetrators, victims, martyrdom, revenge

162 There has been extensive discussion of this issue. For some critical aspects, see Gerard Libaridian, "The Past as a Prison, the Past as a Different Future," Turkish Policy Quarterly 4 (2005), http://turkishpolicy.com/article/168/the-past-as-a-prison-the-past-as-a-different-futurewinter-2005 (last accessed 12 May 2021); as well as various contributions in Alexis Demirdjian, ed., The Armenian Genocide Legacy (New York: Palgrave Macmillan, 2016); and Eldad Ben Aharon, "Recognition of the Armenian Genocide after Its Centenary: A Comparative Analysis of Changing Parliamentary Positions," Israel Journal of Foreign Affairs 13, 3 (2019): 339-52. 